\title{
Modelling biogeochemical fluxes across a Mediterranean fish cage farm
}

\author{
Daniele Brigolin ${ }^{1, *}$, Virna Loana Meccia' ${ }^{1}$, Chiara Venier $^{1}$, Paolo Tomassetti ${ }^{2}$, \\ Salvatore Porrello ${ }^{2}$, Roberto Pastres ${ }^{1}$
}

${ }^{1}$ Department of Environmental Sciences, Informatics and Statistics, Università Ca' Foscari Venezia, Calle larga S. Marta 2137, 30123 Venice, Italy

${ }^{2}$ ISPRA, Italian National Institute for Environmental Protection and Research, via di Casalotti 300, 00168 Rome, Italy

\begin{abstract}
An integrated approach is described for modelling interactions between off-shore fish cages and biogeochemical fluxes of carbon $(\mathrm{C})$, nitrogen $(\mathrm{N})$ and phosphorus $(\mathrm{P})$. Two individual-based population dynamic models for European seabass Dicentrarchus labrax and gilthead seabream Sparus aurata were coupled with a Lagrangian deposition and a benthic degradation model. The individual models explicitly take into account the effects of water temperature and feed availability on fish growth. The integrated model was tested at a Mediterranean fish farm where a comprehensive set of in situ environmental and husbandry data was available. Tests were performed to compare the predicted and observed total organic carbon (TOC) concentrations in surface sediment under and near fish cages. At a local scale, the model output simulated the spatial distribution of 4 biogeochemical indicators, namely: TOC concentrations, C fluxes towards the seabed and C:N and C:P ratios. These allowed the most impacted areas and more extended areas of intermediate organic enrichment to be identified. The model was also used for estimating the mass balance of $\mathrm{C}, \mathrm{N}$ and $\mathrm{P}$, in order to determine the potential cumulative effects of multiple fish farms in the same area. The $\mathrm{C}, \mathrm{N}$ and $\mathrm{P}$ fluxes among feed, fish and environment were calculated for each fish species over 24 mo of farm activity. The results showed that the amount of dissolved $\mathrm{N}$ directly released into the water column in inorganic form (ammonia/urea) was comparable to that deposited on the seafloor in particulate form as uneaten feed and faeces. A larger fraction of $\mathrm{P}$ (about $65 \%$ ) was released as faeces. Results from the integrated model yielded useful information for assessing the sustainability of an area for aquaculture activities that could be used to provide a scientific rationale for fish farm development in new areas.
\end{abstract}

KEY WORDS: Nutrient budgets · Marine spatial planning $\cdot$ Ecosystem approach to aquaculture Cage farming $\cdot$ Individual-based model $\cdot$ Particle tracking model

\section{INTRODUCTION}

European seabass Dicentrarchus labrax L., 1758 and gilthead seabream Sparus aurata L., 1758 account for $95 \%$ of the Mediterranean finfish mariculture production (around $10^{5}$ tons yearly during the last decade; FAO FishstatJ 2012). Greece, Turkey, Spain, Italy, Croatia and France, the major producers using net pen rearing systems, account for $>90 \%$ of the total production (FAO FishstatJ 2012). At the scale of

*Corresponding author: brigo@unive.it the Mediterranean basin, the production of both $D$. labrax and $S$. aurata has increased in the last decade (GFCM 2010), and thus has increased the demand for new aquaculture leases. The trend has stimulated a debate concerning, on the one hand, the need for adopting an ecosystem approach to site selection and framing the allocation of areas dedicated to aquaculture activities within the broader context of the Marine Spatial Planning (MSP) (Douvere \& Ehler 2009), and, on the other, of harmonizing the procedures

(C) The authors 2014. Open Access under Creative Commons by Attribution Licence. Use, distribution and reproduction are unrestricted. Authors and original publication must be credited. 
for Environmental Impact Assessment (EIA) (IUCN 2009) of fish farms.

Several previous publications provide evidence that the carrying capacity of a site must be correctly assessed in EIAs in order to avoid negative effects on the pelagic and benthic ecosystem due to the sedimentation and mineralization of feed particles and faecal pellets (Karakassis et al. 2000, Papageorgiou et al. 2010). Clearly, such consequences should be minimized in order to avoid ecosystem degradation and negative effects that reduce the social acceptability of aquaculture and, therefore, may hinder further investment in that sector. From the producer's point of view, in order to ensure sustainable growth of the Mediterranean finfish aquaculture industry, new sites assigned should not be restricted to remote areas with difficult acees and/or low water quality (J. Ojeda unpubl. data). As a matter of fact, regulators are required to give voice to different groups of coastal stakeholders, possibly providing a scientific rationale for their decisions concerning site selection, in order to guarantee the sustainable development of the aquaculture industry, in compliance with the European Marine Strategy Framework Directive (Directive 2008/56/EC, European Union 2008). Mathematical models and the Geographical Information System represent key resources for supporting decision making and augmenting site-selection transparency (Ferreira et al. 2010, Aguilar-Manjarrez et al. 2008), and these tools are already being used to define the shape and size of the so-called Allowable Zone of Effect of a fish farm (AZE) (GFCM 2012).

When implementing an ecosystem-based approach to site selection, it is important to select a suitable set of indicators for assessing the degree of interaction between aquaculture facilities and the surrounding environment. Different sets of biological and chemical variables have been proposed for evaluating the local-scale interaction between fish cages and the benthic ecosystem (Giles 2008, Hargrave 2010). Most mathematical models which, thus far, have been applied to EIA net pens, only permit modifications of benthic indicators to be predicted at a local scale (González et al. 2002, Holmer et al. 2005, Jusup et al. 2007, Cromey et al. 2012; see also www.ecasatoolbox.org).

Nonetheless, the estimation of cumulative effects of farms located in the same area at a larger spatial scale should also be taken into account in designing procedures for the allocation of new zones for aquaculture, based on the ecosystem approach. The estimates of fluxes of organic carbon
(C), nitrogen (N) and phosphorus (P) across a fish farm represent useful preliminary information for addressing this issue (Strain \& Hargrave 2005, Olsen et al. 2008). These fluxes can be obtained using mass-balance models, which explicitly calculate the metabolism of farmed fish in relation to key environmental forcings, such as water temperature and dissolved oxygen concentration, and to husbandry practices taking into account feed quality/ quantity; thus, simulating cumulative growth over time through a culture cycle. These models can also be used for exploring the sensitivity of fish growth and environment interactions to global changes (FAO 2008), as well as to incorporate improvements in feed composition and feeding practices (EATIP 2012).

This study presents a new model framework, designed for assisting site selection. The integrated model, besides enabling one to assess benthic effects of cage culture, allows one to predict (1) fluxes of $\mathrm{C}$, $\mathrm{N}$ and $\mathrm{P}$ towards the sea bed and concentrations in surface sediment, as well as (2) the budgets of $\mathrm{C}, \mathrm{N}$ and $\mathrm{P}$ derived from mass-balance calculations.

We report a case study as a 'proof of concept' of the model's capability of:

(1) Estimating the spatial distributions of indicators of sediment organic matter and water column nutrient enrichment around a farm site

(2) Estimating C, N and P fluxes across a representative seabass/seabream cage, using as input data on feed composition and feeding regime

(3) Using local indicators for comparing the effects of different husbandry (feeding) practices on mass balance calculations.

\section{METHODS}

The integrated model includes:

(1) Two individual-based population dynamic models (IB-PDM), one each for seabass Dicentrarchus labrax and seabream Sparus aurata, based on a previously described model for seabream by Brigolin et al. (2010)

(2) A Lagrangian model, which was applied for simulating the deposition of faeces and uneaten feed on the seabed (Jusup et al. 2007)

(3) A steady-state benthic degradation model, which was used for estimating the organic enrichment of surface sediment (Brigolin et al. 2009b)

The present methodological section focuses on the aspects related to the integration of the above models and the testing of the integrated model. 
Table 1. Parameters used in the Dicentrarchus labrax growth model and their sources

\begin{tabular}{|c|c|c|c|c|}
\hline Parameter & Description & Value & Unit & Source \\
\hline$I_{\max }$ & Maximum ingestion rate & 0.05 & $g$ feed $g$ fish $^{-m} \mathrm{~d}^{-1}$ & $\begin{array}{l}\text { Estimated on ingestion data reported } \\
\text { by Lupatsch et al. (2001) }\end{array}$ \\
\hline$\alpha$ & Feeding catabolism coefficient & 0.3 & - & Stirling (1977) \\
\hline$\beta_{\mathrm{P}}$ & Assimilation coefficient for protein & 0.88 & - & Dosdat (2001), Moreira et al. (2008) \\
\hline$\beta_{\mathrm{C}}$ & Assimilation coefficient for carbohydrate & 0.84 & - & $\begin{array}{l}\text { Estimated values from Boujard et al. } \\
\text { (2004), Krogdahl et al. (2005) }\end{array}$ \\
\hline$\beta_{\mathrm{L}}$ & Assimilation coefficient for lipid & 0.97 & - & Dosdat (2001), Boujard et al. (2004) \\
\hline$\varepsilon_{\mathrm{P}}$ & Energy content of protein & 23.6 & $\mathrm{~kJ} \mathrm{~g}^{-1}$ & $\begin{array}{l}\text { Brett \& Groves (1979), Requena et al. } \\
\text { (1997) }\end{array}$ \\
\hline$\varepsilon_{\mathrm{C}}$ & Energy content of carbohydrate & 17.2 & $\mathrm{~kJ} \mathrm{~g}^{-1}$ & $\begin{array}{l}\text { Brett \& Groves (1979), Requena et al. } \\
\text { (1997) }\end{array}$ \\
\hline$\varepsilon_{\mathrm{L}}$ & Energy content of lipid & 36.2 & $\mathrm{~kJ} \mathrm{~g}^{-1}$ & $\begin{array}{l}\text { Brett \& Groves (1979), Requena et al. } \\
\text { (1997) }\end{array}$ \\
\hline$\varepsilon_{\mathrm{O} 2}$ & $\begin{array}{l}\text { Energy consumed by the respiration of } \\
1 \mathrm{~g} \text { of oxygen }\end{array}$ & 13.6 & $\mathrm{~kJ} \mathrm{~g} \mathrm{O}_{2}^{-1}$ & Brafield \& Solomon (1972) \\
\hline$\varepsilon_{\mathrm{T}}$ & Energy content of somatic tissue & 9.18 & $\mathrm{~kJ} \mathrm{~g}^{-1}$ & $\begin{array}{l}\text { Estimated from caloric content measure- } \\
\text { ments reported by Lupatsch et al. } \\
\text { (2003) (mean value for 25-500 g } \\
\text { individuals) }\end{array}$ \\
\hline$p k$ & $\begin{array}{l}\text { Temperature coefficient for the fasting } \\
\text { catabolism }\end{array}$ & 0.05 & ${ }^{\circ} \mathrm{C}^{-1}$ & $\begin{array}{l}\text { Estimated from standard metabolic rate } \\
\text { measurements performed by Claireaux } \\
\text { \& Lagardère (1999) }\end{array}$ \\
\hline$k_{0}$ & Fasting catabolism at $0^{\circ} \mathrm{C}$ & 0.00069 & $\mathrm{~g} \mathrm{O}_{2} \mathrm{~g} \mathrm{fish}^{-1} \mathrm{~d}^{-1}$ & $\begin{array}{l}\text { Estimated from standard metabolic rate } \\
\text { measurements performed by Claireaux } \\
\text { \& Lagardère (1999) }\end{array}$ \\
\hline$m$ & Weight exponent for the anabolism & 0.6 & - & $\begin{array}{l}\text { Estimated on ingestion data reported by } \\
\text { Lupatsch et al. (2001) }\end{array}$ \\
\hline$n$ & Weight exponent for the catabolism & 1.0 & - & Ursin $(1967)$ \\
\hline$b$ & Shape coefficient for the $H\left(T_{\mathrm{w}}\right)$ function & 0.23 & - & Calibration \\
\hline$T_{\mathrm{o}}$ & Optimal temperature for Dicentrarchus labrax & 22 & ${ }^{\circ} \mathrm{C}$ & $\begin{array}{l}\text { Barnabé (1990), Eroldogan et al. (2004), } \\
\text { de Walderstein (1990), Claireaux \& } \\
\text { Lagardère (1999) }\end{array}$ \\
\hline$T_{\mathrm{m}}$ & Maximum lethal temperature for Dicentrarchus labrax & 32 & ${ }^{\circ} \mathrm{C}$ & Barnabé (1990) in Dalla Via et al. (1998) \\
\hline$T_{\mathrm{a}}$ & Lowest feeding temperature for Dicentrarchus labrax & 7 & ${ }^{\circ} \mathrm{C}$ & $\begin{array}{l}\text { Tesseyre (1979) and Pastoureaud (1991) } \\
\text { in Dalla Via et al. (1998) }\end{array}$ \\
\hline
\end{tabular}

\section{Individual and cage models}

The seabream and seabass individual models, based on the energy-balance equation described for seabream in Brigolin et al. (2010), are reported in Supplement 1 at www.int-res.com/articles/suppl/ q005p071_supp.pdf. The model predicts evolution of the length and weight of an individual fish in time and allows one to estimate the daily amount of uneaten feed, the daily release of faeces and the daily excretion of ammonia/urea and reactive $\mathrm{P}$. The model is forced by water temperature, feed ration and composition (protein, carbohydrate and lipid content). The initial condition is the wet weight of individuals used to stock cages.

The application of the model to Dicentrarchus labrax required the estimation of 19 parameters (Supplement 1); 18 were determined on the basis of published literature. Parameter $b$, which determines the shape of the function that links the rate of anabolism, $H\left(T_{\mathrm{w}}\right)$, to water temperature, was derived using a comprehensive data set as described in 'Study site and field data description' below. The full parameterization of the seabass model, which represents an original result of this paper, is summarized in Table 1.

The dynamics of the number of individuals of the $i^{\text {th }}$ species within a cage is given by:

$$
\frac{\mathrm{d} N_{i}}{\mathrm{~d} t}=-m_{i} \cdot N_{i}-h_{i}(t) \cdot N_{i}
$$

where $N_{i}$ represented the number of fish, while $m_{i}$ and $h_{i}(t)$, respectively, are natural mortality and harvesting rates. $h_{i}(t)$ is null, except on the days in which harvesting takes place. The weight structure of the population is simulated assuming that the initial weights are normally distributed, and each individual is characterized by a slightly different set of parameters, in order to account for differences in phenotypes 
among the individuals of a cohort. The calculations were made using a set of repeated Monte Carlo simulations on a virtual population of 5000 individuals, as described by Brigolin et al. (2009a). The overall 'appetite' of a fish cage at a given time $t, I_{\mathrm{TOT}}$, was calculated according to Eq. (2), which takes into account the instantaneous species-specific ingestion rate, $I_{i}(w, t)$ (see Eq. S2 in Table S1 in Supplement 1), as well as the abundance and the weight structure of each population:

$$
I_{\mathrm{TOT}}(t)=\sum_{i=1}^{k}\left[N_{i}(t) \int_{0}^{\infty} I_{i}(w, t) \cdot f_{i}(w, t) \mathrm{d} w\right]
$$

where $k$ represents the number of different species reared in the same cage and $f(w, t)$ specifies the fraction of individuals with weight comprised between $w$ and $w+\mathrm{d} w$. In the case examined in this work, in which 2 species are farmed, $a$ and $b$, the total feed ration, provided by the farmer at time $t, R(t)$, was partitioned as follows:

$$
\left\{\begin{array}{l}
R_{a}(t)=R(t) \cdot \frac{N_{a}(t-1) \cdot \int_{0}^{\infty} I_{a}(w, t-1) \cdot f_{a}(w, t-1) \mathrm{d} w}{I_{\mathrm{TOT}}(t-1)} \\
R_{b}(t)=R(t) \cdot \frac{N_{b}(t-1) \cdot \int_{0}^{\infty} I_{b}(w, t-1) \cdot f_{b}(w, t-1) \mathrm{d} w}{I_{\mathrm{TOT}}(t-1)}
\end{array}\right.
$$

according to the relative appetite of each population at time $t-1$.

The model allows the computation of the fluxes of C, N and P exchanged among 3 main compartments, namely farmed fish, water column and surface sediment, on the basis of time series of feed quantity and quality (see Fig. S1 in Supplement 1). These fluxes can be integrated over time, in order to obtain the total budget for each compartment. In our case study, the estimation was carried out separately for seabream and seabass, by integrating them over a time window of 24 mo. The results were subsequently normalized to $1000 \mathrm{~kg}$ of fish harvested. Initial quantities of $\mathrm{C}, \mathrm{N}$ and $\mathrm{P}$ stocked as fingerlings were added to the cage budget. As described by Brigolin et al. (2009a), the values of the fluxes associated with the metabolic activities of the farmed population, $\Phi$, were estimated by integrating the generic individual daily fluxes, $\varphi$ (see Supplement 1 for a definition of $I, A, F$, $O, E x)$, over the size structure of the population, and over time, based on the following equation:

$\Phi=\int_{0}^{T} N(t) \int_{0}^{\infty} \varphi \cdot f(w, t) \mathrm{d} w \mathrm{~d} t \quad$ with $\varphi=I, A, F, O, E X$

C, N and P assimilated in fish tissues and egested as faeces were calculated using the individual mod-
Table 2. Elemental compositions $\left(\mathrm{g} \mathrm{g}^{-1}\right.$ ) of the 3 classes of macromolecules considered in the model

\begin{tabular}{|lccc|}
\hline Class of macromolecule & $\mathrm{P}$ & $\mathrm{N}$ & $\mathrm{C}$ \\
\hline Proteins & 0.4 & 15.9 & 54.5 \\
Lipids & 2.3 & 2.6 & 77.0 \\
Carbohydrates & 0 & 0 & 40.0 \\
\hline
\end{tabular}

els, taking into account the different digestibility of proteins, lipids and carbohydrates $\left(\beta_{\mathrm{P}}, \beta_{\mathrm{C}}, \beta_{\mathrm{L}}\right)$ and the elemental compositions of the 3 classes of macromolecules (Table 2). The fraction of inorganic carbon released to the water column through respiration was calculated according to Eq. (S9) in Table S1, which takes into account the oxygen consumption due to active and basal metabolism. The amount of nitrogen released as urea and ammonia excretion was assumed to be proportional to the respiration rate (Eq. S10 in Table S1), with a conversion coefficient $k_{\mathrm{N}: \mathrm{O}}\left(0.06 \mathrm{~g} \mathrm{~N} \mathrm{~g}^{-1} \mathrm{O}\right)$ based on experiments with Dicentrarchus labrax (Person-Le Ruyet et al. 2004). Since no data could be found relating reactive P excretion to the active metabolism of seabass/seabream, $\mathrm{P}$ excretion was assumed to be proportional to ammonia/urea excretion based on a conversion coefficient $k_{\mathrm{P}: \mathrm{N}}$ of $0.05 \mathrm{~g} \mathrm{P} \mathrm{g}^{-1} \mathrm{~N}$ (Lupatsch \& Kissil 1998).

\section{Lagrangian deposition model and early diagenesis model}

The transport and deposition of uneaten feed particles and fish faeces on the sea bed was simulated using the particle-tracking KK3D numerical model (Jusup et al. 2007), which implements a Lagrangian technique, consistent with the advection-diffusion equation (Rodean 1996). The model was validated by comparing its predictions with sediment trap data collected at a seabass/seabream farm located in Croatia, Central Adriatic (Jusup et al. 2009). Goodness-of-fit analysis showed that the KK3D accounts for $>75 \%$ of variance in the observed data, which range between 8.90 and $54.24 \mathrm{~g}$ dry weight $\mathrm{m}^{-2} \mathrm{~d}^{-1}$ (Jusup et al. 2009). The model requires as input time series of water velocity and fluxes of uneaten feed and fish faeces. The latter variables are provided by the fish cage model which assigns a $\mathrm{C}, \mathrm{N}$ and $\mathrm{P}$ content to each generic particle, $L_{\mathrm{C}: \mathrm{N}: \mathrm{P}}$, based on the following equation:

$$
L_{\mathrm{C}: \mathrm{N}: \mathrm{P}}=\frac{1}{m} \cdot \sum_{i=1}^{k}\left[N_{i}(t) \cdot \int_{0}^{\infty} \varphi_{i}(t) \cdot f_{i}(w, t) \mathrm{d} w\right]
$$

with $\varphi=F_{\mathrm{C}: \mathrm{N}: \mathrm{P}}, W_{\mathrm{C}: \mathrm{N}: \mathrm{P}}$ 
where $F_{\mathrm{C}: \mathrm{N}: / \mathrm{P}}$ and $W_{\mathrm{C}: \mathrm{N}: \mathrm{P}}$, respectively, represent faeces and wasted feed individual fluxes (see Table S1) and associated stoichiometries (Table 2 and Eq. S5 in Table S1), while $m$ is the number of launched particles per type of deposit.

The initial position of faecal particles is chosen at random within the volume occupied by a cage, while uneaten feed pellets start falling from the sea surface. The readily soluble fraction of faeces was assumed to be $15 \%$ (Olsen et al. 2008 and references cited therein).

The deposition model provides as output the daily spatial distribution of the fluxes of organic $\mathrm{C}, \mathrm{N}$ and $P$ towards the sea bed (in $\mathrm{g} \mathrm{m}^{-2} \mathrm{~d}^{-1}$ ). Such fluxes, which are measured by means of sediment trap, are unlikely to be collected in routine monitoring programmes, including instead variables such as total organic carbon (TOC) (GFCM 2012). In order to facilitate the comparison with field data and, at the same time, provide indicators which could be more easily correlated to the functioning of the benthic communities, C fluxes were converted into organic carbon concentrations in surface sediment by means of a steady-state simple early diagenesis model. The model was applied by assuming a $1 \mathrm{~cm}$ deep active surface sediment layer and a fixed sediment density of $2.5 \mathrm{~g} \mathrm{~cm}^{-1}$ (Cermelj et al. 1997). The degradation of organic carbon in a surface sediment core was simulated by means of a first-order decay kinetic with a constant of $10 \mathrm{yr}^{-1}$ (e.g. Brigolin et al. 2009b). This degradation rate was considered as representative of the ranges reported in previous studies (Cromey et al. 1998, Brigolin et al. 2009b), although not similar to values based on surface sediment oxygen demand around salmon farm sites discussed by Strain \& Hargrave (2005). Organic N and P concentrations in the sediment were estimated on the basis of the organic carbon concentration by taking into account differences in the $\mathrm{C}: \mathrm{N}: \mathrm{P}$ ratios of sedimented particles.

\section{Study site and field data description}

The data used for the calibration and validation of the seabass individual model were collected at 2 farms located in Porto Ercole, Tyrrhenian Sea, and Bisceglie, Adriatic Sea, see Fig. 1. The calibration was carried out by comparing the time series of predicted and observed weights collected at Porto Ercole. The time series of the forcing functions, namely daily values of water temperature and fish feed, were estimated by interpolating the monthly data provided by the farm. The model was subsequently validated against an independent data set, made up of 3 time series of data collected at Porto Ercole and 6 time series collected at Bisceglie farms. Data were collected over a time frame covering $10 \mathrm{yr}$, from 1998 to 2007.

The integrated model was applied to a seabass/ seabream farm located in an open coastal area, in the Adriatic Sea, $3200 \mathrm{~m}$ north-east of the Bisceglie harbour (Fig. 1). This area is characterized by a flat bathymetry, with a mean depth of approximately $22 \mathrm{~m}$. According to Porrello et al. (2007), the site is not sheltered and it is exposed to the north and east
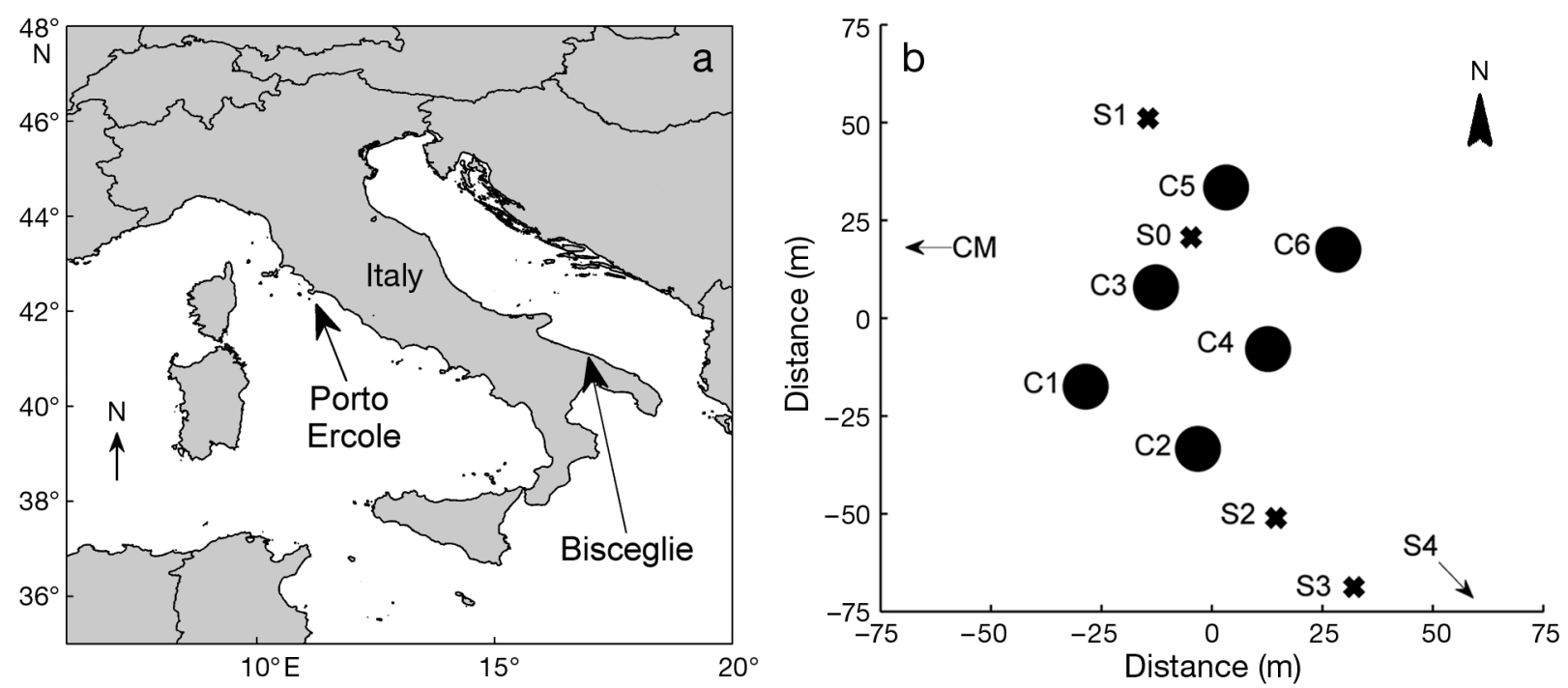

Fig. 1. (a) Location of the 2 fish farms studied in this work: the seabass Dicentrarchus labrax growth model was calibrated in Porto Ercole, and tested at both sites; the integrated model was tested in Bisceglie. (b) Layout of the Bisceglie cage module, where spatially explicit simulations were carried out. Cx: cages; $\mathrm{Sx}$ : sampling stations; S4: reference station, located $900 \mathrm{~m}$ from cages; CM: current meter, located $300 \mathrm{~m}$ from cages 
winds, and sediment is composed of mixed sandmud. The farm was established in 1991 and is made up of four 6-cage modules, $15 \mathrm{~m}$ in diameter and $10 \mathrm{~m}$ in depth. The average annual production is around 600 tons of fish per year.

Data concerning husbandry and feeding practices, as well as water temperature, were collected routinely by the farm personnel. The data set included: (1) daily water temperatures from March 2004 to December 2005, (2) the number of individuals seeded and harvested for each cycle and (3) monthly values of quantities of feed supplied to each cage. The average feed composition was $44 \%$ protein, $21 \%$ lipid and $19 \%$ carbohydrate.

A 270 d long time series of water current data was collected at the farm site in 2006. From 3 March to 18 July, the current was measured by means of a single point current meter Valeport 808 moored at $20 \mathrm{~m}$ water depth; from 24 July to 18 December, by means of an ADCP RDI Sentinel 600 placed $90 \mathrm{~cm}$ above the seabed, according to the methodology explained by Porrello et al. (2005). Current meters were placed at a distance of $300 \mathrm{~m}$ from the centre of the group of cages (see Fig. 1).

TOC concentrations were measured on surface sediment collected in April 2007. Samples were obtained by means of a van Veen grab $\left(0.1 \mathrm{~m}^{2}, 25 \mathrm{l}\right)$ at 5 different stations (Fig. 1): S0 was located at the centre of the cages; S1 was $25 \mathrm{~m}$ to the NW of the external edge of the cages; S2 and S3 were 25 and $50 \mathrm{~m}$ to the SE of the cages, respectively; and S4 was located 900 $\mathrm{m}$ from the cages and selected as a pristine reference station. Replicate sub-samples from surface sediment ( 0 to $2 \mathrm{~cm}$ ) were collected from the grab with plastic corer tubes and immediately frozen $\left(-20^{\circ} \mathrm{C}\right)$ for the determination of TOC. Analyses were carried out by means of a CHNS Elemental Analyzers EA 1100 Thermofinnigan.

\section{Simulation set-up}

The integrated model was applied to the 6-cage module shown in Fig. 1. The 24 mo long simulation covers the longest period on which information on husbandry and feeding practices was available, corresponding to the duration of $>1$ complete typical rearing cycle (approximately 15 mo according to Halwart et al. 2007). In fact, a preliminary analysis of the fish farm stocking-harvesting tables revealed that Sparus aurata and Dicentrarchus labrax farming cycles overlapped and that each species was reared either in isolation or together with the other one (see
Supplement 2 at www.int-res.com/articles/suppl/q005 p071_supp.pdf). Therefore, it was decided to start the simulation on 1 March 2004 to provide results representative of biogeochemical interactions at steady state.

The evolution of the 2 reared populations in time was estimated using Eq. (1); however, based on a preliminary analysis of fish density time series, the natural mortality rate was found to be much less than that due to harvest and was therefore set to 0 . Monthly values of feed were linearly interpolated, in order to obtain an estimate of the daily food ration. The time series of current-meter measurements did not cover the entire simulation period, and missing data were estimated by means of a classical harmonic analysis applied to the available time series (Pawlowicz et al. 2002). Monthly observations of water temperature were provided by the farmers from March 2004 to December 2005. Data for January and February 2006 were obtained as mixed layer temperature downloaded from the EMIS website (EMIS-JRC, http://emis.jrc.ec.europa.eu; a comparison among in situ data and EMIS-JRC data is shown in Fig. S2 in Supplement 2).

The values of the parameters used in the deposition model are presented in Table 3 . Grid resolution $(5 \times 5 \mathrm{~m})$, time step (60 s) and number of particles launched every day (10000) are within the ranges suggested in the literature for depositional models (Cromey et al. 2002, Pérez et al. 2002). These values were selected on the basis of a set of preliminary tests performed by varying systematically the parameters, and they correspond to the values over which an increase in the computational effort did not produce relevant changes in the accuracy of the predicted deposition patterns. A constant depth of $22 \mathrm{~m}$ was considered, and each cage was modelled as a cylinder with radius of $7.5 \mathrm{~m}$. The settling velocity of each particle was randomly selected from a normal distribution (parameters are reported in Table 3 ).

As described in the 'Introduction', the model was designed to respond to major external forcing variables, namely water temperature and feed quality/ quantity. A demonstration of the potential use of the model for predicting the effects of changes in feeding technology was conducted by repeating the simulation with feed settling velocity reduced to reflect the use of feed with higher buoyancy and lower sedimentation rate. The second type of feed had identical composition, but settling velocity was $8.7 \pm 0.8 \mathrm{~cm} \mathrm{~s}^{-1}$. This sedimentation velocity was selected from the lower hand of the values measured for different types of feed pellets in Mediterranean waters (Vassallo et al. 2006) . 
Table 3. Parameters used in the deposition model and their sources

\begin{tabular}{|c|c|c|c|c|}
\hline Parameter & Description & Value & Unit & Source \\
\hline $\mathrm{d} x, \mathrm{~d} y$ & Horizontal resolution & 5 & $\mathrm{~m}$ & Cromey et al. (2002), Pérez et al. (2002) \\
\hline $\mathrm{d} t$ & Time step & 60 & $\mathrm{~s}$ & - \\
\hline$K_{x^{\prime}} K_{y}$ & Horizontal eddy diffusivity coefficient & 0.1 & $\mathrm{~m}^{2} \mathrm{~s}^{-1}$ & Cromey et al. (2002), Jusup et al. (2007) \\
\hline$K_{z}$ & Vertical eddy diffusivity coefficient & 0.001 & $\mathrm{~m}^{2} \mathrm{~s}^{-1}$ & Cromey et al. (2002), Jusup et al. (2007) \\
\hline$W_{\text {fo }}$ & Normal distribution of settling velocity of feed & $\begin{array}{l}\mu=14.4 \\
\sigma=1.1\end{array}$ & $\mathrm{~cm} \mathrm{~s}^{-1}$ & Porrello et al. (2007) \\
\hline$W_{\text {fadl }}$ & $\begin{array}{l}\text { Normal distribution of settling velocity of } \\
\text { Dicentrarchus labrax faeces }\end{array}$ & $\begin{array}{l}\mu=0.7 \\
\sigma=0.07\end{array}$ & $\mathrm{~cm} \mathrm{~s}^{-1}$ & Magill et al. (2006) \\
\hline$W_{\text {fasa }}$ & $\begin{array}{l}\text { Normal distribution of settling velocity of } \\
\text { Sparus aurata faeces }\end{array}$ & $\begin{array}{l}\mu=0.5 \\
\sigma=0.05\end{array}$ & $\mathrm{~cm} \mathrm{~s}^{-1}$ & Magill et al. (2006) \\
\hline$K_{\mathrm{d}}$ & Degradation constant & 5 & $\mathrm{yr}^{-1}$ & Cromey et al. (1998) \\
\hline
\end{tabular}

The integrated model was coded in FORTRAN. The ordinary differential equations in IB-PDM were numerically solved by means of a 4 th-order RungeKutta scheme, while the Lagrangian equation for the deposition model was solved following Jusup et al. (2007). Models were coupled by re-scaling the daily output provided by the IB-PDM and maintaining constant the input of uneaten food and faeces to the deposition model over the $24 \mathrm{~h}$. The calibration of $b$ was carried out starting from an initial weight of $40 \mathrm{~g}$ and searching the minimum of the goal function:

$$
\Gamma=\sum_{i=1}^{n}\left(W_{i}-\hat{W}_{i}\right)^{2}
$$

where $W_{i}$ and $\hat{W}_{i}$ represent observed and predicted wet weight of the fish, respectively. The goodnessof-fit in the prediction was assessed quantitatively according to Smith \& Rose (1995), by testing the difference of slope and intercept of the regression line, respectively, from 1 and 0 .

\section{RESULTS}

\section{Calibration and validation of the Dicentrarchus labrax model}

The results of the calibration of the $b$ parameter is presented in Fig. 2. The value which minimized the goal function $\Gamma$ (Eq. 6) was 0.23, with an $\mathrm{R}^{2}$ of 0.998 . Model validation was carried out by comparing the model results with 3 time series of data collected at Porto Ercole and 6 time series of data collected at Bisceglie. The time series of predicted and observed wet weights, together with water temperatures, are plotted in Fig. S3 and Fig. S4 of Supplement 2 for each of the 9 simulations. The results, in terms of goodness-of-fit, are summarized in Fig. 3, which presents a scatter plot of the observed versus predicted weights. The comparison, which pertains to a sample of size 85, indicates that the aim of minimizing the difference between observed and predicted wet weight was successful. The model performed

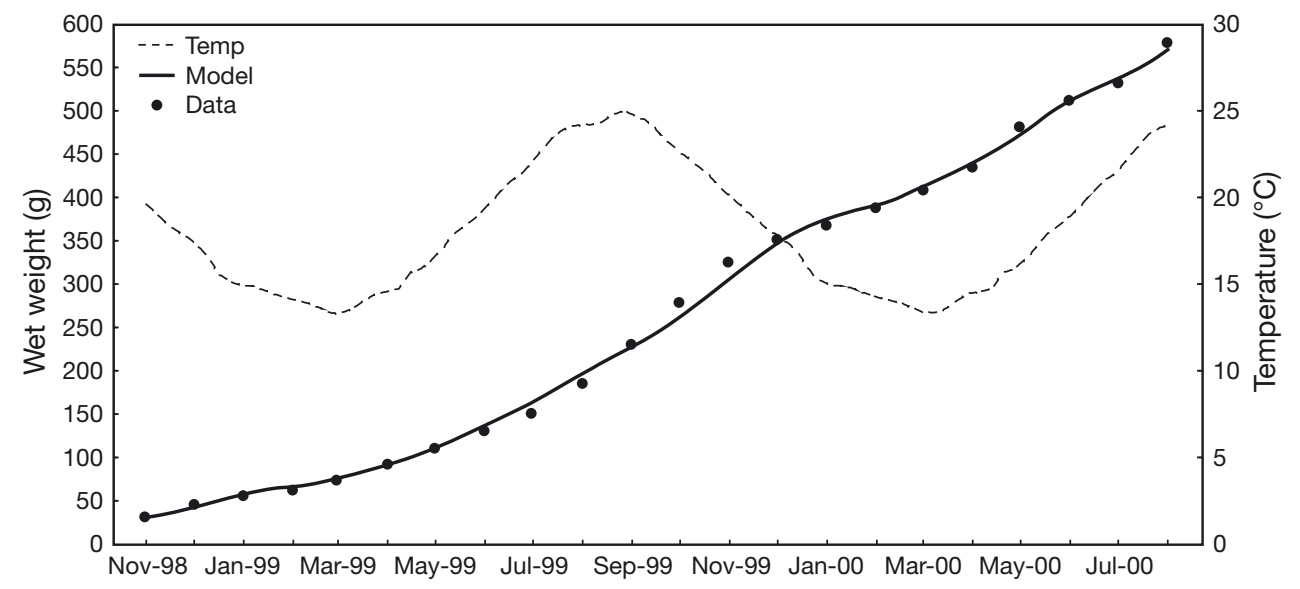

Fig. 2. Calibration of the Dicentrarchus labrax growth model. Dashed line corresponds to the water temperature $\left({ }^{\circ} \mathrm{C}\right)$; continuous line represents the wet weight $(\mathrm{g})$ predicted by the model; dots indicate the wet weight observations (g) 
well $\left(R^{2}=0.946\right.$, slope of the regression line $=1.037$ and intercept $=8.5$ ). These values are not significantly different, respectively, from 1 and $0(\alpha=0.05)$.

\section{Evolution of fish biomass and cage emissions}

An example of the results provided by the 24 mo simulation can be seen in Fig. 4a,b. As far as the growth rate is concerned, the model results correspond to the percentage daily weight gain measured by Lupatsch et al. (2003), within the same temperature range. In Cage 6, the Sparus aurata, with an initial average weight of $24 \mathrm{~g}$, reached a final weight of approximately $530 \mathrm{~g}$ in about $15 \mathrm{mo}$, while in Cage 4, Dicentrarchus labrax, with an initial weight of $40 \mathrm{~g}$, reached $415 \mathrm{~g}$ in about $18 \mathrm{mo}$. The model predicted marked decreases in seabream weight during winter months, $13.1 \%$ in Cage 6 (Fig. 4a) from December to March, when the water temperature falls below the threshold of $12^{\circ} \mathrm{C}$, the temperature around which the fish stops feeding. Such decreases were not as pronounced for seabass (approximately $2.7 \%$ in Cage $4 ;$ Fig. 4 b), since the water temperature did not fall below $7^{\circ} \mathrm{C}$, the critical temperature for this species.

The differences in the metabolic responses of the 2 species to water temperature resulted in slightly different dynamics in faeces production and uneaten feed during the year (Fig. 5a,b). The total amount of faeces discharged is higher in Cage 4 than in Cage 6, $2310 \mathrm{~kg}$ versus $1293 \mathrm{~kg}$, due to the higher number of individuals reared, and the higher winter activity of
Dicentrarchus labrax. Nonetheless, peaks in faeces production per individual are more pronounced in the case of Sparus aurata (average values can be derived from the total loads and the number of individuals), which, according to the model, has a higher capacity for feed ingestion.

\section{Organic deposition and enrichment in surface sediment}

The results of the deposition model are summarized in Fig. 6a. The figure shows the spatial distribution of the average daily flux of organic carbon (g $\mathrm{C} \mathrm{m}^{-2} \mathrm{~d}^{-1}$ ) over the 24 mo long simulation. The origin of the spatial coordinates coincides with the centre of the 6 -cage module, while white circles represent the position of each cage (see Fig. 1b). The spatial pattern has a WNW-ESE orientation, since the deposition model is driven by the local hydrodynamics; the latter is characterized by a dominant current along the WNW-ESE axis, as can be seen in Fig. 6b. Current meter data confirmed that the site is characterized by high velocities (maximum value: $46.7 \mathrm{~cm} \mathrm{~s}^{-1}$ ). The highest fluxes of organic carbon, $\varphi_{\mathrm{OC}}>5 \mathrm{~g} \mathrm{C} \mathrm{m}^{-2} \mathrm{~d}^{-1}$ (maximum value: $21 \mathrm{~g} \mathrm{C} \mathrm{m}^{-2} \mathrm{~d}^{-1}$ ), were found in a restricted area located between the cages, and were due to the deposition of uneaten feed pellets, the settling velocity of which was an order of magnitude higher than that of the faeces (Table 3). In fact, the deposition of fish faeces affects a wider area, which presents values of organic carbon $\varphi_{\mathrm{OC}}<5 \mathrm{~g} \mathrm{C} \mathrm{m}^{-2} \mathrm{~d}^{-1}$. P enrichment, indicated by

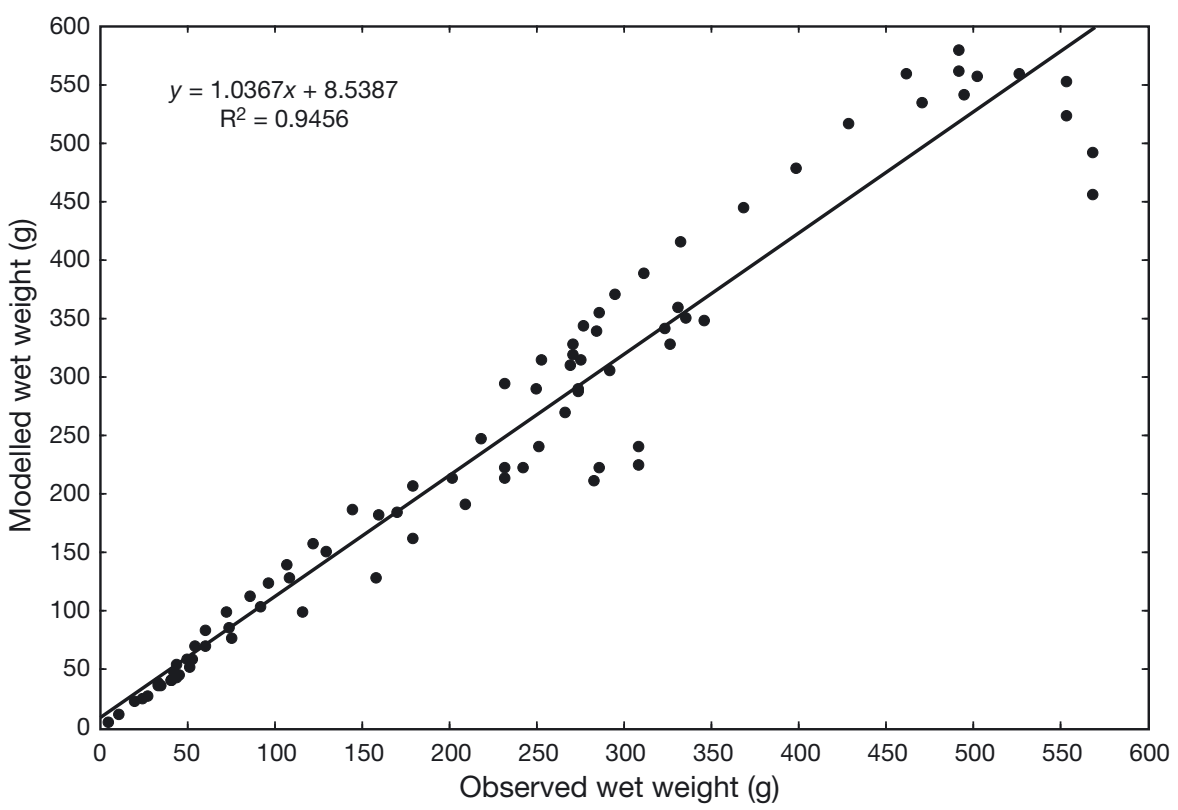

Fig. 3. Dicentrarchus labrax growth model validation: observed versus predicted weights; 85 observations were compared with model predictions; 3 series of data correspond to Porto Ercole in the Tyrrhenian Sea, and 6 series correspond to Bisceglie in the southern Adriatic Sea (the complete set of results is reported in Supplement 2) 
Fig. 4. (a) Sparus aurata and (b) Dicentrarchus labrax simulated growth curves in Bisceglie. The predicted evolution of the wet weight of 2 cohorts reared in Cages 6 and 4 . The solid lines represent the average weight of the individuals in the cohort, while the shaded area represents the standard deviation of the population around the mean value. Series of water temperature are also shown (dashed line)
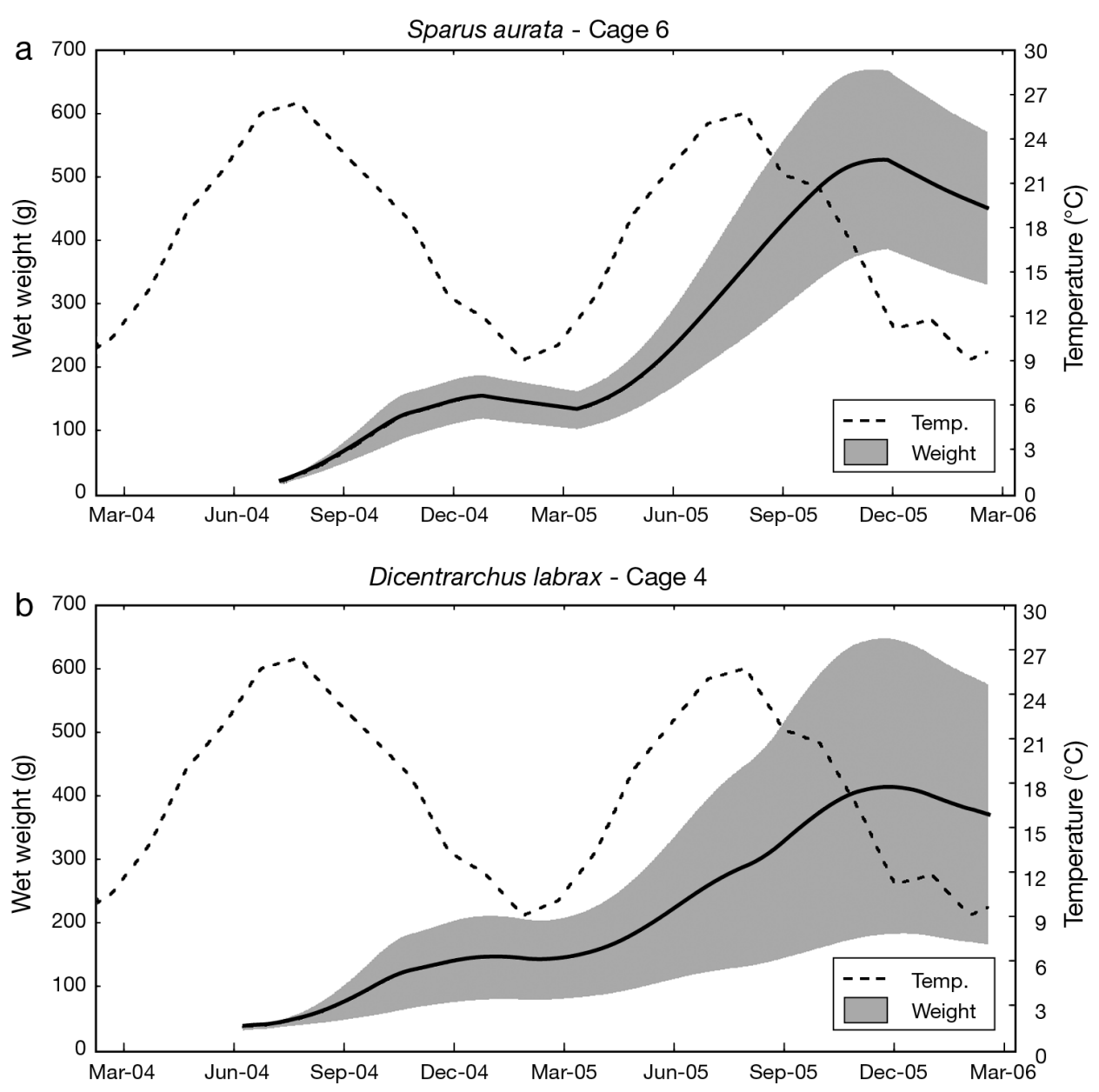

lower C:P values (Fig. 6d), was localized underneath the cages. A gradient in C:N (Fig. 6c) was distributed along a transect with a WNW-ESE orientation. C:P values were always higher than the Redfield ratio (minimum value: $\sim 150 \mathrm{~mol} \mathrm{C} \mathrm{mol}^{-1} \mathrm{P}$ ), while $\mathrm{C}: \mathrm{N}$ ratios were $<6.6 \mathrm{~mol} \mathrm{C} \mathrm{mol}^{-1} \mathrm{~N}$ in the most affected areas, indicating $\mathrm{N}$ enrichment.

$\mathrm{C}$ fluxes presented in Fig. 6a were compared with recalculated values based on the lower feed pellet settling velocity (Fig. 7). Results as absolute differences show that the lower feed pellet settling rate decreased the peak of $\varphi_{\mathrm{OC}}$ from 21 to $15 \mathrm{~g} \mathrm{C} \mathrm{m}^{-2} \mathrm{~d}^{-1}$. However, the decrease only occurred in areas where $\mathrm{C}$ flux was $\geq 15 \mathrm{~g} \mathrm{C} \mathrm{m}^{-2} \mathrm{~d}^{-1}$. This localized reduction was accompanied by an increase in the total area, with moderate to high $\mathrm{C}$ flux values $>2 \mathrm{~g} \mathrm{C} \mathrm{m}^{-2} \mathrm{~d}^{-1}$.

The concentration of organic carbon in surface sediment (Fig. 8a) shows an expected horizontal pattern, reflecting estimated carbon flux with the maximum $\mathrm{C}$ concentration $(\sim 6 \%)$ near the centre of the farm. Fig. $8 \mathrm{~b}$ shows the area affected by a severe impact $\left(\sim 125 \mathrm{~m}^{2},>3.5 \%\right)$ and the maximum radius of the area with concentrations $>1 \%(\sim 25 \mathrm{~m}$ to the NE). The model results concerning TOC concentrations were compared with surface sediment observations at stations S0, S1, S2 and S3 (Fig. 1) collected in April 2007, approximately 4 mo following the end of the simulation period. The TOC concentration recorded at $\mathrm{S} 4$ (Fig. 1), 0.4\%, was assumed to be representative of the area in pristine conditions; therefore, values were added to the predicted ones. The predicted concentrations at the grid point nearest each sampling station were then compared with the observed ones (Fig. 8c). The model correctly simulated the order of magnitude of the observed concentrations and also showed the observed concentration gradient between the S0 station located underneath the cages and S3 (values at $\mathrm{S} 0$ were $\sim 1.75$ times higher than values at $\mathrm{S} 3)$. However, the concentrations predicted at $\mathrm{S} 1$ and $\mathrm{S} 2$, located at $25 \mathrm{~m} \mathrm{NW}$ and SE, respectively, from the edge of the cages, were slightly higher than observed values. Finally, the model underestimated TOC concentrations at S3, which nevertheless were higher than those at $\mathrm{S} 2$, closer to the cages. 

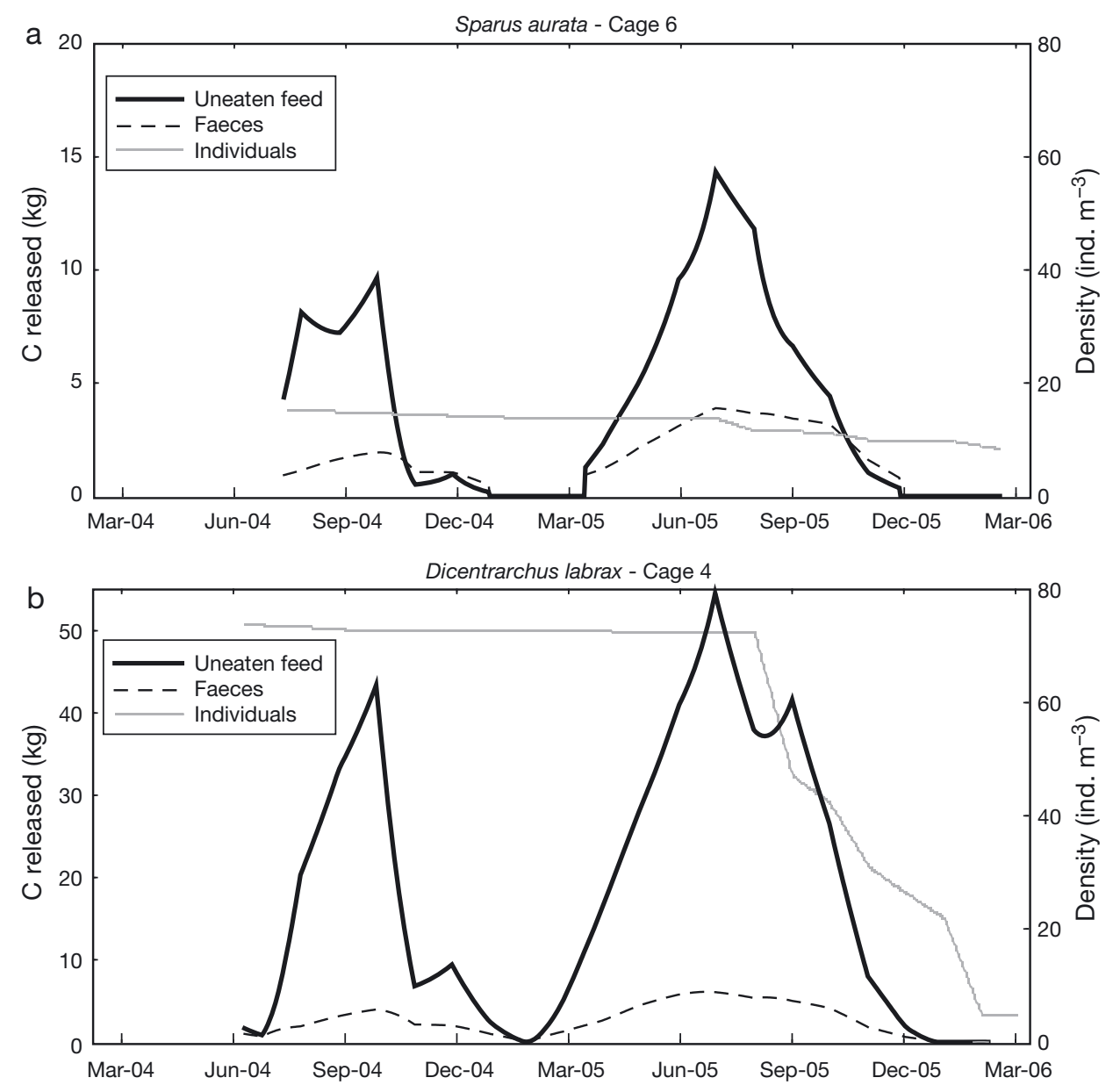

Fig. 5. Sparus aurata, Dicentrarchus labrax. Uneaten feed (solid black line) and faeces (dashed line) discharged, as predicted by the model (a) for Cage 6, S. aurata and (b) for Cage 4, D. labrax. C released in total fish outputs, not normalized for number of individuals (black lines). Fish density in the cage (grey line); cage volume approx $1765 \mathrm{~m}^{3}$

\section{C, $\mathbf{N}$ and $P$ budgets}

The estimated production of the 6 -cage module was almost 70 tons of seabream and 146 tons of seabass in 34 mo. The $\mathrm{C}, \mathrm{N}$ and $\mathrm{P}$ fluxes among the fish cages, the surrounding water column and the surface sediments were integrated over this time frame, and, subsequently, normalized to 1 ton of production of each species (Fig. 9a,b). Approximately $33 \%$ of the feed given to Sparus aurata and $38 \%$ of that given to Dicentrarchus labrax were released in the environment either as uneaten feed or faeces: C discharged as faeces accounts for approximately $17 \%$ (S. aurata) or $9.6 \%$ (D. labrax) of the C ingested as feed. The highest input of $\mathrm{N}$ to the environment was represented by direct excretion of dissolved $\mathrm{N}$ as ammonia and urea for the 2 species, (S. aurata: $53 \mathrm{~kg}$ ton $^{-1}, D$. labrax: $50 \mathrm{~kg} \mathrm{ton}{ }^{-1}$ ). The order of magnitude of these $\mathrm{N}$ fluxes is comparable to the sum of organic wastes represented by uneaten feed and faeces $(S$. aurata: $57 \mathrm{~kg}$, D. labrax: $53 \mathrm{~kg}$ ), with these particles sinking rapidly and providing local organic enrichment to the surface sediment (experimentally meas- ured sinking velocities of 14.4 and 0.5 to $0.7 \mathrm{~cm} \mathrm{~s}^{-1}$ for feed and faeces particles, respectively, were used in our model). $\mathrm{N}$ and $\mathrm{P}$ contents in fish tissues were calculated by closing the budgets: they ranged, respectively, from 2.3 to $1.5 \%$ and from 0.43 to $0.35 \%$.

\section{DISCUSSION}

\section{Virtual model of a farmed population}

The estimates of surface sediment TOC concentrations, C fluxes, C:N, C:P ratios and $\mathrm{C}, \mathrm{N}$ and $\mathrm{P}$ budgets depend on the modelling of fish metabolism. The new individual model for Dicentrarchus labrax presented here supplements existing models (Arias 1980, Muller-Feuga 1990, Kaushik 1998, Pagand et al. 2000) that did not explicitly consider the dependence of fish metabolism on water temperature and feed quantity or quality. The previous models do not allow one to estimate oxygen consumption, excretion, faeces production, or waste feed release for either seabream Sparus aurata or seabass D. labrax. Lupatsch et al. 

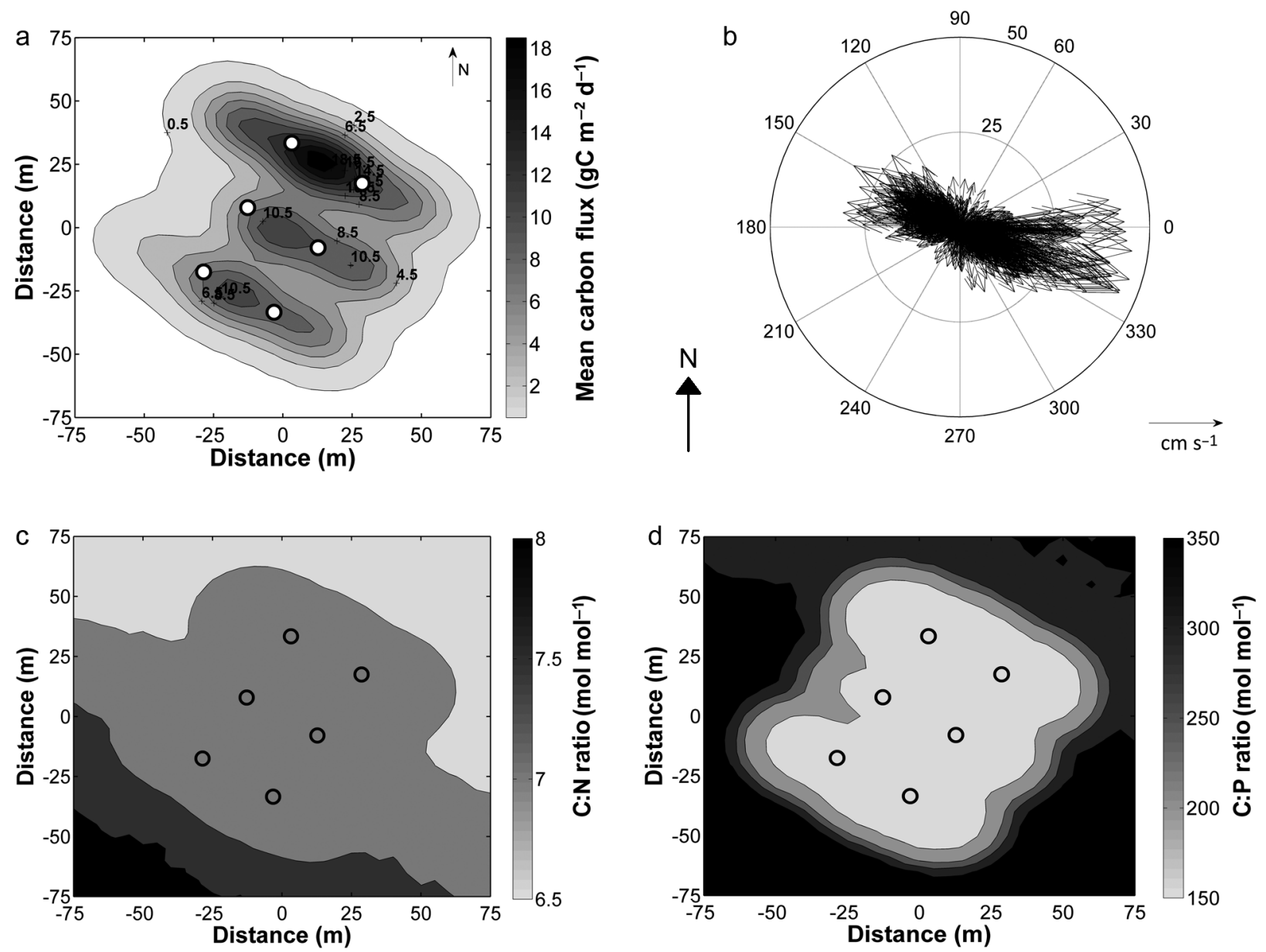

Fig. 6. Organic deposition: integrated model results under the 6-cage module in Bisceglie. (a) Mean daily organic carbon flux $\left(\mathrm{g} \mathrm{C} \mathrm{m}^{-2} \mathrm{~d}^{-1}\right.$ ) for the period March 2004 to December 2006; (b) module and directions of the water currents, as measured at the farm site; and (c,d) model-predicted C:N and C:P atomic ratios in sedimented organic matter

(2001, 2003) proposed a more detailed empirical model relating seabass weight with feed intake, based on an extensive set of measurements carried out at temperatures between 19 and $27^{\circ} \mathrm{C}$. Unfortunately, the restricted thermal regime considered in these experiments prevented us from applying this model in the temperate area studied in this work. The quantitative comparison between the results of our model and different sets of observations carried out in this work suggests that individual growth is adequately predicted. This result was achieved on the basis of a model parameterization, which, for 18 over 19 parameters, was carried out based on experimental studies of the physiology and nutrition of this species. $\mathrm{N}$ and $\mathrm{P}$ contents in fish tissues, which were calculated by closing the budgets, compare well with those reported by Lemarié et al. (1998), with respect to $D$. labrax, $1.4 \% \mathrm{~N}$ and $0.6 \% \mathrm{P}$ on a wet weight basis. The fact that our results were consistent with these numbers can be seen as an indirect indication that the model is likely to simulate fish metabolism with accuracy.

\section{Indicators of local-scale interaction}

The results presented in the previous section provide information concerning some biogeochemical variables that can be used to indicate farm-scale (local) effects of benthic organic enrichment and that might be used in a site-selection process for the allocation of new aquaculture leases. Hyland et al. (2005) compared datasets of TOC concentrations and macroinfaunal communities for 7 coastal regions and identified 2 critical thresholds corresponding to no stress for benthic fauna $(<1.0 \%$ TOC) and severe stress $(>3.5 \%$ TOC). Based on these values, the area affected by a severe impact $(>3.5 \%)$ and the maximum radius of the area with concentrations $>1 \%$ (Fig. 8b) provide easy-to-interpret measures of the 


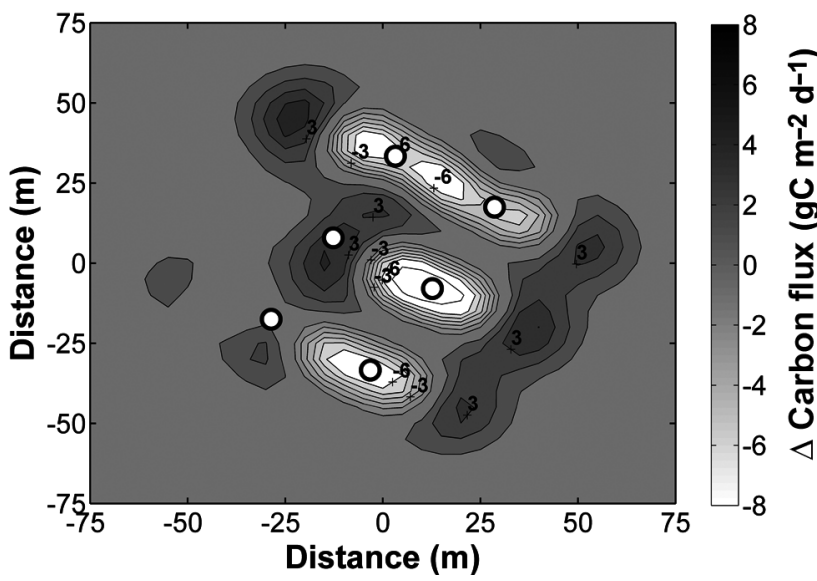

Fig. 7. C flux anomalies $\left(\mathrm{g} \mathrm{C} \mathrm{m}^{-2} \mathrm{~d}^{-1}\right)$ induced by a change in the feed provided, the new feed being characterized by a lower sedimentation velocity

extent of the zone affected by particulate wastes released by the farm.

Other biogeochemical indicators directly derived from model outputs are C:N and C:P molar ratios in organic matter released by the farm (Fig. 6c,d). These patterns reflect the order of magnitude higher settling rate for feed pellets over faeces (Table 3 ) and their different $\mathrm{N}$ and $\mathrm{P}$ contents. The different $\mathrm{N}$ and $\mathrm{P}$ concentrations in feed and faeces released by the farm can be a major source of variability for the organic matter rain, affecting pore waters and sediment geochemistry and, in turn, for benthic infauna. Field investigations are needed to increase knowledge concerning relationships between downward fluxes of organic matter, early diagenesis processes in surface sediments and the structure of benthic faunal communities (e.g. Stucchi et al. 2005, Chamberlain \& Stucchi 2007).

As far as organic carbon fluxes are concerned, several studies (Dahlbäck \& Gunnarson 1981, Hargrave 1994, 2010 Wildish et al. 2001, Holmer et al. 2005, Chamberlain \& Stucchi 2007) suggest that a transition in benthic status from 'healthy' to 'degraded' conditions may occur at around 1 to $2 \mathrm{~g} \mathrm{C} \mathrm{m}^{-2} \mathrm{~d}^{-1}$. Cromey et al. (1998) identified 3 thresholds, namely: (1) $\varphi_{\mathrm{OC}}>0.1 \mathrm{~g} \mathrm{C} \mathrm{m}^{-2} \mathrm{~d}^{-1}$ (low organic enrichment), (2) $\varphi_{\mathrm{OC}}=0.1$ to $1 \mathrm{~g} \mathrm{C} \mathrm{m}^{-2} \mathrm{~d}^{-1}$ (moderate organic enrichment) and (3) $\varphi_{\mathrm{OC}}>1.6 \mathrm{~g} \mathrm{C} \mathrm{m}^{-2} \mathrm{~d}^{-1}$ (degraded environment). Based on these thresholds, $\mathrm{C}$ fluxes predicted by the model indicate that moderate benthic organic enrichment $\left(>0.5 \mathrm{~g} \mathrm{C} \mathrm{m}^{-2} \mathrm{~d}^{-1}\right)$ occurred up to $50 \mathrm{~m}$ from the farm site. The zone of effect estimated using the average flux of organic $\mathrm{C}$ (Fig. 8a) would be larger than that obtained by using the TOC concentrations (not shown), but is still consistent with
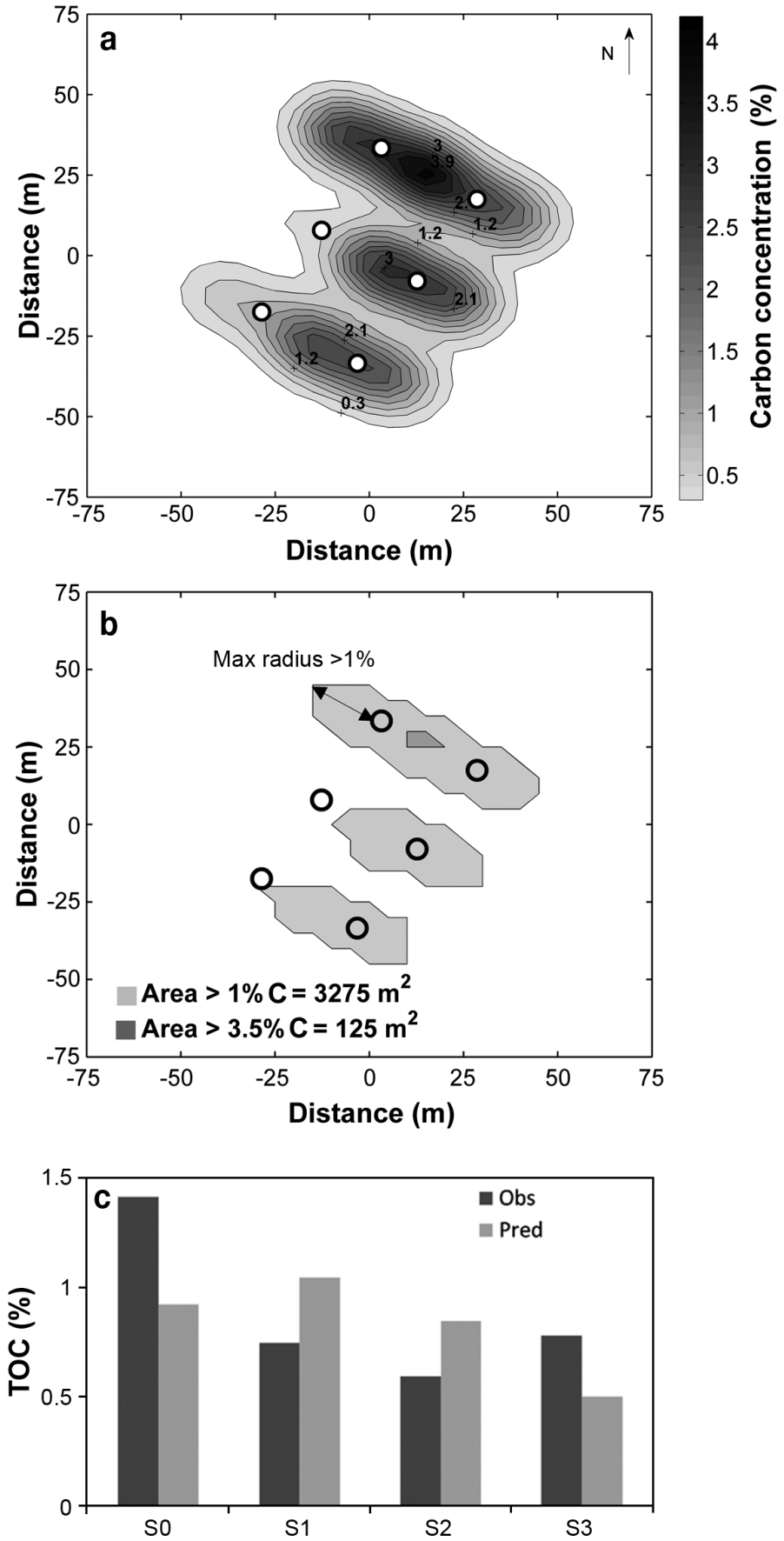

Fig. 8. (a) Modelled organic carbon concentration (\%) in the upper sediment at the end of the simulated period; (b) zones of intermediate and high organic enrichment underneath the farm studied in Bisceglie; (c) comparison between observed (Obs) and model-predicted (Pred) total organic carbon (TOC) concentration at 4 stations located underneath the farm (see Fig. 1). Arrow in (b) shows the maximum radius of the area with carbon concentrations $>1 \%$

the results presented by Porrello et al. (2005), which were obtained in an area characterized by hydrodynamic and bathymetric conditions similar to those 

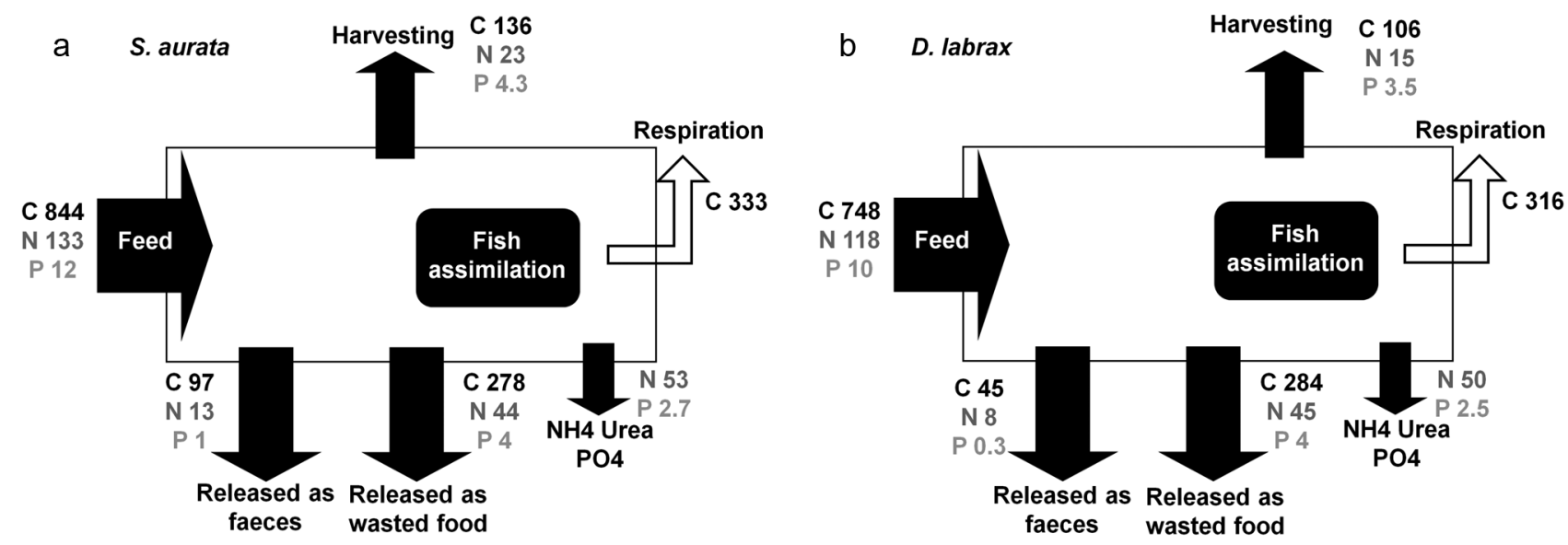

Fig. 9. Sparus aurata (a), Dicentrarchus labrax (b). Estimates of C, N and P fluxes (kg), per 1 ton of fish produced, exchanged between the different reservoirs (feed, fish, environment) over the whole simulated period

found at our study site. The authors detected significant benthic organic enrichment within a distance of $50 \mathrm{~m}$ around the cages.

Although sediment traps have been used to validate predicted $\mathrm{C}$ fluxes around fish aquaculture sites in other studies (e.g. Cromey et al. 2002, Stucchi et al. 2005, Chamberlain \& Stucchi 2007, Jusup et al. 2009), no sediment traps were deployed in the present study, so, unfortunately, C fluxes predicted by the model cannot be evaluated. In order to validate the KK3D model, Jusup et al. (2009) placed sediment traps at $23 \mathrm{~m}$ depth, at a fish farm producing approximately 400 tons $\mathrm{yr}^{-1}$, and found fluxes ranging from 8.90 to $54.24 \mathrm{~g}$ dry weight $\mathrm{m}^{-2} \mathrm{~d}^{-1}$. By considering $\mathrm{C}$ contents of, respectively, $49.6 \%$ and $27.7 \%$ in feed and faeces (Brigolin et al. 2009b) and an equal load of the 2 deposits, the fluxes determined by Jusup et al. (2009) range between 3.44 and $20.96 \mathrm{~g} \mathrm{C} \mathrm{m}^{-2} \mathrm{~d}^{-1}$. Therefore, the maximum peak obtained at $21 \mathrm{~g} \mathrm{C} \mathrm{m}^{-2}$ $\mathrm{d}^{-1}$ in the present simulation is in accordance with the experimental range of these fluxes. Simulation results were also compared to the TOC concentrations measured in surface sediment (Fig. 8c). Although the model correctly simulated the order of magnitude, the spatial gradient between stations was not satisfactorily reproduced. In general, the comparison between the model output and the observations is sensitive to the uncertainty in the position of the station, in particular in areas characterized by sharp gradients. At S3 the TOC concentration measured was higher than that at S2, located closer to the cages, suggesting that this latter station may have been affected by another source of organic pollution. In this case, the influence of other cage modules in the area is unlikely, since the closest location is
$>150 \mathrm{~m}$ from the edge of S3. The concentration pattern highlights that Cage 1 and Cage 3 contribute less to the deposition compared with the remaining cages. This is related to the lower number of individuals (seabass + seabream) stocked in these cages during the simulated period (data not shown). With respect to this, misreporting of the farmed density in these cages may also partially explain the mismatch between predicted and observed concentrations at S0. The lack of agreement in the spatial pattern of concentrations could also be related to our modelling assumptions. The critical erosion shear stress found by Cromey et al. (2002) was associated with a nearbed current speed of approximately $9.5 \mathrm{~cm} \mathrm{~s}^{-1}$. Considering that ca. one-third of the current meter data recorded in this work were above this threshold, inclusion of a resuspension module would be a mandatory step in improving the particle-tracking module. $\mathrm{S} 0$ is located close to the centre of the farm, where a reduction in water velocity is expected, as well as a consequent increase in sedimentation, due to the drag effect of the cages. The inclusion of this process in the particle-tracking module could also improve the soundness of the results.

The example presented in Fig. 7 was selected to illustrate how this class of models can be used to estimate the response of indicators of local organic enrichment to changes in husbandry practices (in line with recommendations by Ferreira et al. 2010). A change in feeding technology was considered by introducing a feed type with identical composition, but lower settling velocity. In this case, results from the mathematical model indicate that the area of sediment undergoing a 'medium effect' would be increased. This type of numerical experiment could be used to 
optimize both economic and environmental aspects of farm management. In relation to this, we advocate that further work should be placed on improving the description of fish-feeding efficiency, in relation to both metabolic conditions and feed properties.

\section{Indicators of interaction at the larger spatial scale: nutrient emissions}

In the last decade, the interest in the estimation of nutrient emissions from cage aquaculture has increased because of more stringent environmental regulations and the need to quantify the potential effects of a large-scale development of the industry on marine ecosystems (Olsen et al. 2008, IUCN 2009). Models have been proposed to assess the interactions of aquaculture with macronutrient cycles (e.g. Lefebvre et al. 2001, Islam 2005, Strain \& Hargrave 2005, Piedecausa et al. 2010, Wild-Allen et al. 2010, Keeley et al. 2013). Islam (2005) identified 2 linear regression models predicting $\mathrm{N}$ and $\mathrm{P}$ emission from fish cages on the basis of the food conversion ratio (FCR-weight of feed provided to weight of fish harvested). The application of the models to our case study, which is characterized by an average FCR of 1.96, yielded $104.7 \mathrm{~kg} \mathrm{~N}$ and $18.8 \mathrm{~kg} \mathrm{P}$ discharged per $1000 \mathrm{~kg}$ of fish produced. This $\mathrm{N}$ value is in good agreement with our predictions $(110 \mathrm{~kg} \mathrm{~N}$ for seabream and $103 \mathrm{~kg} \mathrm{~N}$ for seabass) (Fig. 9a,b). However, according to our model, 7.7 and $6.8 \mathrm{~kg} P$ would be released for each ton of seabream and seabass produced, respectively. These estimates are about one-third of that derived from the model by Islam (2005). The results reported in Fig. 9a,b show very high proportions of feed waste (33 and $38 \%$ on a C base for seabream and seabass, respectively). These values are much higher than those given in previous studies for Atlantic salmon (Strain \& Hargrave 2005, Stucchi et al. 2005), which range from 5 to $10 \%$. Such values suggest that there is a margin left for improving the efficiency of the industry by controlling the wasting of a costly resource that is not contributing to fish growth. The use of species-specific models considering the dependence of metabolic processes on water temperature, such as the ones presented here, could help in addressing this issue.

Lefebvre et al. (2001) developed a 0-dimensional model of the cycling of $\mathrm{N}$ in a saltmarsh ecosystem dominated by intensive Dicentrarchus labrax pond farming. The authors found that $19 \%$ of the ingested $\mathrm{N}$ was retained in fish tissues, a value comparable to our estimates (13 to $17 \%$ ). According to the same model, $61 \%$ of the $\mathrm{N}$ contained in the feed was released as dissolved components. Our model predicts a direct discharge of inorganic $\mathrm{N}$ to the water column of between 40 and $42 \%$ of the quantity ingested. However, farm deposits are extremely labile and are readily mineralized, thus providing an additional source of macronutrients for the water column (Cromey et al. 1998, Strain \& Hargrave 2005, Brigolin et al. 2009b). Treating the organic $\mathrm{N}$ deposited on the seabed as conservative and accounting for the inorganic $\mathrm{N}$ released into the water column after organic matter mineralization, according to the simple early diagenesis model used, the overall inorganic $\mathrm{N}$ contribution amounts to $60 \%$ of the quantity ingested in $28 \mathrm{~d}$. It is also worth noting with respect to Lefebvre et al. (2001) that the model presented here extends the estimation of nutrient emissions to $\mathrm{P}$, which is of primary interest in understanding the potential effects on primary productivity in systems limited by this element, such as the Adriatic Sea (Zavatarelli et al. 1998).

Tsagaraki et al. (2011) presented a more complex approach, involving the use of a reaction-transport biogeochemical model, based on a modified version of ERSEM (Baretta et al. 1995). In this model the amounts of $\mathrm{N}$ and $\mathrm{P}$ released by a farm are estimated on the basis of a mass-balance approach based on the works by Lupatsch \& Kissil (1998) and Tsapakis et al. (2006), without explicitly considering the dependence of metabolic processes on water temperature. The model presented here could improve the description of the impacts of a fish farm on the pelagic ecosystem, by replacing the simplified steady-state mass-balance approach with a model which dynamically simulates responses to environmental forcings. Since computational resources are becoming increasingly powerful, a number of 3dimensional spatially explicit operational biogeochemical models, which could be fully coupled with the farm model presented in this work, are becoming available (e.g. EUROCEANS, www.eur-oceans.eu; MEECE, www.meece.eu; OPEC, http://marine-opec. $\mathrm{eu} /$ ). With respect to this perspective, the present model would also allow one to quantify the oxygen consumption by fish in relation to water temperature and feeding regimes. This term could be included in the mass-balance equation for the dissolved oxygen concentration, a state variable included in most biogeochemical models. The simulation of dissolved oxygen dynamics within and close to fish cages could be important in some areas, since low oxygen levels can increase the risk of diseases and are regarded as an indicator of poor conditions for fish growth (Johansson et al. 2006). These ideas are in agreement 
with the work by Page et al. (2005), who described a simple oxygen depletion index for identifying areas where respiration by caged salmon could alter localand regional-scale dissolved oxygen concentrations. Also, Strain \& Hargrave (2005) adopted this approach to evaluate the impact of salmon pens on dissolved oxygen in different sites where salmon aquaculture is concentrated in the Bay of Fundy. In this regard, it is worth noting that the management of the risk of disease and the control of the health of reared fish are key objectives of the European marine aquaculture strategic research and innovation agenda (EATIP 2012).

\section{Concluding remarks}

Implementation of the ecosystem approach to aquaculture will increasingly require the use of spatial planning and modelling tools as a support for decision making in aquaculture. The integrated model described in this study can provide useful local-scale screening-level indicators to assist with site selection. Also, by allowing consideration of the effects of different feeding practices, it can support the sustainable management of a farm. As currently formulated, the model allows the simulation of the overall 'appetite' of a fish cage, based on the weight spectra of the 2 reared populations. This represents a generic approach that could be extended to other species and different types of integrated multi-species aquaculture. $\mathrm{C}, \mathrm{N}$ and $\mathrm{P}$ budgets were considered to gather preliminary information on how a farm site interacts at a larger spatial scale. Results showed that the amount of inorganic $\mathrm{N}$ released into the water column as dissolved ammonia/urea was comparable to the $\mathrm{N}$ deposited on the seafloor as uneaten feed and faeces. Since a major source (about $65 \%$ ) of P comes from the mineralization of organic matter, a detailed description of processes related to $\mathrm{P}$ non-conservative behaviour in the sediment should be added to the early diagenesis module. Simulated organic matter fluxes could be used to force a detailed model of early diagenesis in surface sediments, in order to predict the fate of the biogeochemical variables of sediment and pore waters under different scenarios of organic matter deposition. This would also provide a basis for assessing consequent shifts in the structure of the benthic community. In addition, the proposed model structure can be coupled with existing 3-dimensional reaction-transport biogeochemical models to evaluate the potential impact of multiple farms at the larger spatial scale.
The model allows one to estimate the concentration of TOC in surface sediments and, therefore, to identify the areas most exposed to severe impacts of benthic organic enrichment, as well as a larger area affected by intermediate enrichment. Simulation results showed that, if predicted $\mathrm{C}$ fluxes are considered rather than sediment TOC concentrations, the extent of the zone of intermediate effect of the farm is larger, approaching a radius of $50 \mathrm{~m}$ from the edge of the farm. Model results also indicate that a spatial gradient in the C:N and C:P ratios in organic matter deposited on the surface sediment is the result of differences in composition and settling velocities of farm wastes and faeces.

Acknowledgements. The authors gratefully acknowledge Mr. Giacomo Marchi for his help in the early stage of model development, and Bisceglie and Porto Ercole farmers. This work has been partly supported by EU Project No. 282977 (MEDINA).

\section{LITERATURE CITED}

Aguilar-Manjarrez J, Kapetsky JM, Soto D (2008) The potential of spatial planning tools to support the ecosystem approach to aquaculture. FAO Fisheries and Aquaculture Proceedings 17. FAO, Rome

Arias A (1980) Crecimiento, regimen alimentario y reproducción de la dorada (Sparus aurata L.) y del róbalo (Dicentrarchus labrax L.) en los esteros de Cádiz. Investig Pesq 44:59-83

> Baretta JW, Ebenhöh W, Ruardij P (1995) The European Regional Seas Ecosystem Model, a complex marine ecosystem model. Neth J Sea Res 33:233-246

Barnabé G (1990) Rearing bass and gilthead bream. In: Barnabé G (ed) Aquaculture, Vol 2. Ellis Horwood, New York, NY, p 647-686

Boujard T, Gélineau A, Covès D, Corraze G, Dutto G, Gasset E, Kaushik SJ (2004) Regulation on feed intake, growth, nutrient and energy utilisation in European sea bass (Dicentrarchus labrax) fed high fat diets. Aquaculture 231:529-545

Brafield AE, Solomon DJ (1972) Oxy-calorific coefficients for animals respiring nitrogenous substrates. Comp Biochem Physiol 43:837-841

Brett JR, Groves TDD (1979) Physiological energetics. In: Hoar WS, Randall DJ, Brett JR (eds) Fish physiology, Vol 8. Academic Press, New York, NY, p 279-353

Brigolin D, Dal Maschio G, Rampazzo F, Giani M, Pastres R (2009a) An individual-based population dynamic model for estimating biomass yield and nutrient fluxes through an off-shore Mytilus galloprovincialis farm. Estuar Coast Shelf Sci 82:365-376

Brigolin D, Pastres R, Nickell TD, Cromey CJ, Aguilera DR, Regnier P (2009b) Modelling the impact of aquaculture on early diagenesis processes in sea loch sediments. Mar Ecol Prog Ser 388:63-80

> Brigolin D, Pastres R, Tomassetti P, Porrello S (2010) Model- 
ling the biomass yield and the impact of seabream mariculture in the Adriatic and Tyrrhenian Seas (Italy). Aquacult Int 18:149-163

Cermelj B, Bertuzzi A, Faganeli J (1997) Modeling of pore water nutrient distribution and benthic fluxes in shallow coastal waters (Gulf of Trieste, northern Adriatic). Water Air Soil Pollut 99:435-443

> Chamberlain J, Stucchi D (2007) Simulating the effects of parameter uncertainty on waste model predictions of marine finfish aquaculture. Aquaculture 272:296-311

> Claireaux G, Lagardère JP (1999) Influence of temperature, oxygen and salinity on the metabolism of the European sea bass. J Sea Res 42:157-168

- Cromey CJ, Black KD, Edwards A, Jack IA (1998) Modelling the deposition and biological effects of organic carbon from marine sewage discharges. Estuar Coast Shelf Sci 47:295-308

Cromey CJ, Nickell TD, Black KD (2002) DEPOMOD—modelling the deposition and biological effects of waste solids from marine cage farms. Aquaculture 214:211-239

> Cromey CJ, Thetmeyer H, Lampadariou N, Black KD, Kögeler J, Karakassis I (2012) MERAMOD: predicting the deposition and benthic impact of aquaculture in the eastern Mediterranean Sea. Aquacult Environ Interact 2: $157-176$

> Dahlbäck B, Gunnarson LAH (1981) Sedimentation and sulphate reduction under a mussel culture. Mar Biol 63: 269-275

Dalla Via J, Villani P, Gasteiger E, Niederstätter H (1998) Oxygen consumption in sea bass fingerling Dicentrarchus labrax exposed to acute salinity and temperature changes: metabolic basis for maximum stocking density estimations. Aquaculture 169:303-313

de Walderstein W (1990) Esperienze di allevamento di orate in gabbie sommerse nel Golfo di Trieste. Hydrores Annuario 7(8):45-49

Dosdat A (2001) Environmental impact of aquaculture in the Mediterranean: nutritional and feeding aspects, Environmental Impact Assessment of Mediterranean Aquaculture Farms. Cah Options Mediterr 55:23-36

$>$ Douvere F, Ehler CN (2009) New perspectives on sea use management: initial findings from European experience with marine spatial planning. J Environ Manage 90: 77-88

EATIP (European Aquaculture Technology and Innovation Platform) (2012) The future of European aquaculture. EATIP, Liege. Available at www.aquamedia.info/PDFFLIP/ EATIPVision/index.html

Eroldogan OT, Kumlu M, Aktas M (2004) Optimum feeding rates for European sea bass Dicentrarchus labrax L. reared in seawater and freshwater. Aquaculture 231:501-515

European Union (2008) Directive 2008/56/EC. Directive of the European parliament and of the Council of 17 June 2008 establishing a framework for community action in the field of marine environmental policy (Marine Strategy Framework Directive). Off J Eur Union 164:19-40

FAO (Food and Agriculture Organisation) (2008) Report of the FAO expert workshop on climate change implications for fisheries and aquaculture. Fish Rep 870. FAO, Rome

FAO FishstatJ (2012) Aquaculture production: quantities 1950-2010. Available at www.fao.org/fishery/statistics/ software/fishstatj/en (accessed 31 March 2014)

Ferreira JG, Aguilar-Manjarrez J, Bacher C, Black K and others (2010) Progressing aquaculture through virtual technology and decision-support tools for novel management. In: Subasinghe RP, Arthur JR, Bartley DM, De Silva SS and others (eds) Proceedings of the Global Conference on Aquaculture, 22-25 September 2010, Phuket, Thailand. FAO, Rome, p 643-704. Available at http:// archimer.ifremer.fr/doc/00086/19747/17387.pdf

GFCM (General Fisheries Commission for the Mediterranean) (2010) WGSC-working group on site selection and carrying capacity. Report of the workshop on allocated zones for aquaculture (AZA). FAO, Rome

GFCM (General Fisheries Commission for the Mediterranean) (2012) Report of the WGSC-ShoCMed Workshop on the definition and environmental monitoring within Allowable Zone of Effect (AZE) of aquaculture activities within the Mediterranean countries. FAO, Rome

Giles H (2008) Using Bayesian networks to examine consistent trends in fish farm benthic impact studies. Aquaculture 274:181-195

González M, Gyssels P, Mader J, Borja A, Galparsoro I, Uriarte A (2002) La modelización numérica de la dispersión de productos de desecho vertidos desde explotaciones de acuicultura: una herramienta para la adecuada gestión medioambiental del sector. Bol Inst Esp Oceanogr 18: $59-65$

Halwart M, Soto D, Arthur JR (2007) Cage aquaculture: regional reviews and global overview. FAO, Rome

Hargrave BT (1994) A benthic enrichment index. In: Hargrave BT (ed) Modeling benthic impacts of organic enrichment from marine aquaculture. Can Tech Rep Fish Aquat Sci 1949:79-91

Hargrave BT (2010) Empirical relationships describing benthic impacts of salmon aquaculture. Aquacult Environ Interact 1:33-46

Holmer M, Wildish D, Hargrave BT (2005) Organic enrichment from marine finfish aquaculture and effects on sediment processes. In: Hargrave BT (ed) Environmental effects of marine finfish aquaculture. Handbook of Environmental Chemistry, Vol 5. Springer-Verlag, Heidelberg, p 186-206

Hyland J, Balthis L, Karakassis I, Magni P and others (2005) Organic carbon content of sediments as an indicator of stress in the marine benthos. Mar Ecol Prog Ser 295: 91-103

Islam MS (2005) Nitrogen and phosphorus budget in coastal and marine cage aquaculture and impacts of effluent loading on ecosystem: review and analysis towards model development. Mar Pollut Bull 50:48-61

IUCN (International Union for the Conservation of Nature) (2009) Guide for the sustainable development of Mediterranean aquaculture. 2. Aquaculture site selection and site management. IUCN, Gland

Johansson D, Ruohonen K, Kiessling A, Oppedal F, Stiansen JE, Kelly M, Juell JE (2006) Effect of environmental factors on swimming depth preferences of Atlantic salmon (Salmo salar L.) and temporal and spatial variations in oxygen levels in sea cages at a fjord site. Aquaculture 254:594-605

> Jusup M, Gecek S, Legovi T (2007) Impact of aquacultures on the marine ecosystem: modelling benthic carbon loading over variable depth. Ecol Modell 200:459-466

Jusup M, Klanjšček J, Petricioli D, Legović T (2009) Predicting aquaculture-derived benthic organic enrichment: model validation. Ecol Modell 220:2407-2414 
Karakassis I, Tsapakis M, Hatziyanni E, Papadopoulou KN, Plaiti W (2000) Impact of cage farming of fish on the seabed in three Mediterranean coastal areas. ICES J Mar Sci 57:1462-1471

Kaushik SJ (1998) Nutritional bioenergetics and estimation of waste production in non-salmonids. Aquat Living Resour 11:211-217

Keeley NB, Cromey CJ, Goodwin EO, Gibbs MT, Macleod CM (2013) Predictive depositional modelling (DEPOMOD) of the interactive effect of current flow and resuspension on ecological impacts beneath salmon farms. Aquacult Environ Interact 3:275-291

> Lefebvre S, Bacher C, Meuret A, Hussenot J (2001) Modelling nitrogen cycling in a mariculture ecosystem as a tool to evaluate its outflow. Estuar Coast Shelf Sci 52: 305-325

> Lemarié G, Martin JLM, Dutto G, Garidou C (1998) Nitrogenous and phosphorous waste production in a flowthrough land-based farm of European seabass (Dicentrarchus labrax). Aquat Living Resour 11:247-254

Lupatsch I, Kissil GW (1998) Predicting aquaculture waste from gilthead seabream (Sparus aurata) culture using a nutritional approach. Aquat Living Resour 11:265-268

Lupatsch I, Kissil GW, Sklan D (2001) Optimization of feeding regimes for European sea bass Dicentrarchus labrax, a factorial approach. Aquaculture 202:289-302

> Lupatsch I, Kissil GW, Sklan D (2003) Comparison of energy and protein efficiency among three fish species gilthead sea bream (Sparus aurata), European sea bass (Dicentrarchus labrax) and white grouper (Epinephelus aeneus): energy expenditure for protein and lipid deposition. Aquaculture 225:175-189

> Magill SH, Thetmeyer H, Cromey CJ (2006) Settling velocity of faecal pellets of gilthead sea bream (Sparus aurata L.) and sea bass (Dicentrarchus labrax L.) and sensitivity analysis using measured data in a deposition model. Aquaculture 251:295-305

Moreira S, Peres H, Couto A, Enes P, Oliva-Teles A (2008) Temperature and dietary carbohydrate level effects on performance and metabolic utilisation of diets in European sea bass (Dicentrarchus labrax) juveniles. Aquaculture 274:153-160

Muller-Feuga A (1990) Modélisation de la croissance des poissons en élevage. Rapp Sci Tech IFREMER 21

Olsen LM, Holmer M, Olsen Y (2008) Perspectives of nutrient emission from fish aquaculture in coastal waters. Literature review with evaluated state of knowledge. Final report FHF Project No. 542014. Fishery and Aquaculture Industry Research Fund, Oslo

Pagand P, Blancheton JP, Casellas C (2000) A model for predicting the quantities of dissolved inorganic nitrogen released in effluents from a sea bass (Dicentrarchus labrax) recirculating water system. Aquacult Eng 22: 137-153

Page F, Losier R, McCurdy P, Greenburg D, Chaffey J, Chang B (2005) Dissolved oxygen and salmon cage culture in the southwestern New Brunswick portion of the Bay of Fundy. In: Hargrave BT (ed) Environmental effects of marine finfish aquaculture. Handbook of Environmental Chemistry, Vol 5. Springer-Verlag, Heidelberg, p 1-28

Papageorgiou N, Kalantzi I, Karakassis I (2010) Effects of fish farming on the biological and geochemical properties of muddy and sandy sediments in the Mediterranean
Sea. Mar Environ Res 69:326-336

> Pastoureaud A (1991) Influence of starvation at low temperatures on utilization of energy reserves, appetite recovery and growth character in sea bass, Dicentrarchus labrax. Aquaculture 99:167-178

Pawlowicz R, Beardsley B, Lentz S (2002) Classical tidal harmonic analysis including error estimates in MATLAB using t_tide. Comput Geosci 28:929-937

Pérez OM, Telfer TC, Beveridge MCM, Ross LG (2002) Geographical information systems (GIS) as a simple tool to aid modelling of particulate waste distribution at marine fish cage sites. Estuar Coast Shelf Sci 54:761-768

Person-Le Ruyet J, Mahé K, Le Bayon N, Le Delliou H (2004) Effects of temperature on growth and metabolism in a Mediterranean population of European sea bass, Dicentrarchus labrax. Aquaculture 237:269-280

Piedecausa MA, Aguado-Giménez F, Cerezo-Valverde J, Hernández-Llorente MD, García-García B (2010) Simulating the temporal pattern of waste production in farmed gilthead seabream (Sparus aurata), European seabass (Dicentrarchus labrax) and Atlantic bluefin tuna (Thunnus thynnus). Ecol Modell 221:634-640

Porrello S, Tomassetti P, Manzueto L, Finoia MG, Persia E, Mercatali I, Stipa P (2005) The influence of marine cages on the sediment chemistry in the western Mediterranean Sea. Aquaculture 249:145-158

Porrello S, Tomassetti P, Persia E, Mercatali I, Gennaro P (2007) Bisceglie (Italy) ECASA study site report. Available at www.ecasatoolbox.org.uk/the-toolbox/eia-country/ study-site-results/study-site-reports/icram-bisceglie-1 (accessed 25 January 2013)

> Requena A, Fernández-Borrás J, Planas J (1997) The effects of a temperature rise on oxygen consumption and energy budget in gilthead sea bream. Aquacult Int 5:415-426

Rodean HC (1996) Stochastic Lagrangian models of turbulent diffusion. American Meteorological Society, Boston

> Stirling HP (1977) Growth, food utilization and effect of social interaction in the European bass Dicentrarchus labrax. Mar Biol 40:173-184

> Smith EP, Rose KA (1995) Model goodness-of-fit analysis using regression and related techniques. Ecol Modell 77 : 49-64

Strain PM, Hargrave BT (2005) Salmon aquaculture, nutrient fluxes and ecosystem processes in southwestern New Brunswick. In: Hargrave BT (ed) Environmental effects of marine finfish aquaculture. Handbook of Environmental Chemistry, Vol 5. Springer-Verlag, Heidelberg, p 29-58

Stucchi D, Sutherland TA, Levings C, Higgs D (2005) Nearfield depositional model for salmon aquaculture waste. In: Hargrave BT (ed) Environmental effects of marine finfish aquaculture. Handbook of Environmental Chemistry, Vol 5. Springer-Verlag, Heidelberg, p 157-180

Tesseyre C (1979) Etude des conditions d'élevage intensif du loup (Dicentrarchus labrax). Doctor's thesis, Université Montpellier II Sciences et Techniques, Montpellier

> Tsagaraki TM, Petihakis G, Tsiaras K, Triantafyllou G and others (2011) Beyond the cage: ecosystem modelling for impact evaluation in aquaculture. Ecol Model 222: 2512-2523

> Tsapakis M, Pitta P, Karakassis I (2006) Nutrients and fine particulate matter released from sea bass (Dicentrarchus labrax) farming. Aquat Living Resour 19:69-75

Ursin E (1967) A mathematical model of some aspects of fish 
growth, respiration and mortality. J Fish Res Board Can 24:2355-2453

- Vassallo P, Doglioli AM, Rinaldi F, Beiso I (2006) Determination of physical behaviour of feed pellets in Mediterranean water. Aquacult Res 37:119-126

Wild-Allen K, Herzfeld M, Thompson PA, Rosebrock U, Parslow J, Volkman JK (2010) Applied coastal biogeochemical modelling to quantify the environmental im-

Editorial responsibility: Kenneth Black,

Oban, UK pact of fish farm nutrients and inform managers. J Mar Syst 81:134-147

Wildish DJ, Hargrave BT, Pohle G (2001) Cost-effective monitoring of organic enrichment resulting from salmon mariculture. ICES J Mar Sci 58:469-476

Zavatarelli M, Raichic F, Bregant D, Russo A, Artegiani A (1998) Climatological biogeochemical characteristics of the Adriatic Sea. J Mar Syst 18:227-263

Submitted: January 28, 2013; Accepted: January 21, 2014

Proofs received from author(s): April 1, 2014 